\title{
Anatomy of chewed leaf blade particles of Cenchrus ciliaris and Lolium perenne in relation to digestion
}

\author{
D Wilman, P Rezvani Moghaddam \\ Department of Agricultural Sciences, University of Wales, Aberystwyth, Dyfed SY23 3DD, UK
}

The thickness and accessibility to microbes of forage cell walls has a major effect on the rate and extent of digestion of forage by ruminants (Wilson, 1993, Chapter 1 of Forage Cell Wall Structure and Digestibility, eds HG Jung et al, American Society of Agronomy). There are large differences between forage species and between different parts of plants in the proportion of thick-walled cells, the thickness of the walls and the extent to which the forage is broken down in the mouth when eaten.

As part of a larger programme, we have examined the anatomy of chewed leaf blade particles and intact blades of Cenchrus ciliaris L. (buffel grass), a tropical grass of low digestibility, and Lolium perenne L. (perennial ryegrass), a temperate grass of high digestibility. The two grasses were grown in identical conditions in a heated glasshouse (mean daily minimum and maximum temperatures 15 and $31^{\circ} \mathrm{C}$, respectively) by Mtengeti (1993, PhD thesis, University of Wales, Aberystwyth). Meals of the two grasses were fed to sheep by Mtengeti and the chewed grass collected via an oesophageal fistula. Within the chewed grass it was possible to distinguish between leaf blade, leaf sheath and stem. The sheep ate $C$. ciliaris more slowly than $L$. perenne, producing smaller, but heavier, particles. The results in the Table are means of two replicates and of two dates of harvest in each of two years. The standard errors are derived from the years $x$ dates $x$ species interaction.

The chewed particles of $C$. ciliaris leaf blades, compared with those of $L$. perenne, had a higher proportion of thick-walled cells, a higher proportion of thick wall within the total area of wall, thicker cell walls in all types of cell, and a much greater volume of walt per $\mathrm{mm}^{3}$ of particle.

On the basis of Wilson (1993) there is time to digest away only about $0.5 \mu \mathrm{m}$ of cell wall thickness during the period leaf particles remain in the rumen (about 25 hours), even if rumen microbes have immediate access to a wall. Thus much of the total volume of wall in C. ciliaris will pass out of the rumen undigested, compared with a relatively small proportion in $L$. perenne. This appears to be a major reason for the difference in digestibility between the two grasses.

\section{Cenchrus ciliaris Lolium perenne SE (3 DF)}

Volume per particle $\left(\mathrm{mm}^{3}\right)$

Number of cells per $\mathrm{mm}^{3}$ of particle ('000) : thick-walled

thin-walled

epidermal

Area of wall, $\mathrm{mm}^{2}$ per $\mathrm{mm}^{3}$ of particle :

thick-walled cells

thin-walled cells

epidermal cells

Thickness of walls $(\mu \mathrm{m})$ :

thick-walled cells

thin-walled cells

epidermal cells :

inner wall

outer wall

Total volume of wall, $\mathrm{mm}^{3}$ per $\mathrm{mm}^{3}$ of particle

\subsection{8}

101

1

3

115

16

58

1.30

0.24

0.45

3.22

0.239
3.40

96

12

8

83

91

65

0.85

0.15

0.22

0.87

0.113
0.038

0.029

0.038

\subsection{3}

21.5

0.8

0.6

12.9

2.0

3.4

0.163

0.0123 